Zagazig J. Agric. Res., Vol. 43 No. (6A) 2016

http:/www.journals.zu.edu.eg/journalDisplay.aspx?Journalld=1\&queryType=Master

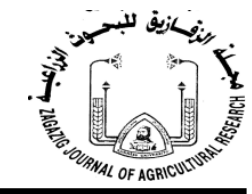

\title{
DEVELOPMENT OF A HARVESTING MACHINE FOR PEANUT
}

\author{
Mostafa A. Nour ${ }^{*}$, M.S. El Shal, M.A. El Shazly and M.M. Ali \\ Agric. Eng. Dept., Fac. Agric., Zagazig Univ., Egypt
}

\begin{abstract}
Field experiments were carried to develop and evaluate a peanut harvesting machine at El-qureen city, Sharkia Governorate, Egypt. The planted peanut crop variety was Giza 6. A harvesting machine has been developed, which performs direct harvesting of peanut. The performance of the developed harvesting machine was conducted under the following parameters: four different forward speeds of 1.5, 2, 2.5 and $3 \mathrm{~km} / \mathrm{hr}$., four different chain speeds of 53.33, 61.67, 70.00 and $78.33 \mathrm{~m} / \mathrm{min}$ and four soil moisture contents (d.b.) of 9.3, 12.4, 15.7 and 18.6\%. The performance of the developed machine was evaluated taking into consideration field capacity, field efficiency, total harvesting losses, machine productivity, required power, specific energy, operating and criterion costs. The experimental results reveal to the following: Forward speed is $2.5 \mathrm{~km} / \mathrm{hr}$., soil moisture content is $15.7 \%$ and the chain speed is $70 \mathrm{~m} / \mathrm{min}$.
\end{abstract}

Key words: Peanut, direct harvesting, developed machine, digging separating.

\section{INTRODUCTION}

Peanut is considered one of the most important legumes and oil crops in the world. The total peanut cultivated area in the world are about 58.07 million faddans yearly producing about 40.23 million $\mathrm{Mg}$ with an average 0.69 $\mathrm{Mg} / \mathrm{fad}$., and the total peanut cultivated area in Egypt are about 0.14 million faddan yearly producing about 0.21 million $\mathrm{Mg}$ with an average $1.47 \mathrm{Mg} /$ fad., according to USDA (2016). Peanut seeds contain a high percentage of oil up to $40-60 \%, 16-28 \%$ protein, some important vitamins, minerals and acids needed for the human body.

Harvesting of groundnut from the field is an important operation in the cultivation of groundnut, which has to be carried out during crop maturity and at optimum time to minimize field losses. Mechanical harvesting offers the possible solution for reducing the cost of peanut production. But a long time consumed, more losses and costs to achieve the mechanical harvesting by using a digger and a special combine, so we need a developed machine to achieve the direct harvesting of peanut. (Mussad, 2001) evaluated the performance of peanut harvesting machine. The total power requirement of a single row was about $14.71 \mathrm{~kW}$ (20 hp). The losses during digging, lifting, stripping and conveying were $6.23 \%, 8.65 \%$, $5.06 \%$ and $1.96 \%$, respectively. Other peanut harvesters had higher digging and stripping losses $(15 \%$ and $9.3 \%$, respectively). The machine pods breakage scored lower percentage at $1.91 \%$ compared with the previous designed machines (about 8.9\%). Overall efficiency was $78.1 \%$, considered high compared with other combines efficiencies. The peanut harvesting machine had an average capacity of 0.325 $\mathrm{Mg} / \mathrm{hr}$. The maximum capacity reached by the machine was about $0.377 \mathrm{Mg} / \mathrm{hr}$., while the previous designed harvester had a maximum capacity of $0.337 \mathrm{Mg} / \mathrm{hr}$., (Mechail, 2003) indicated that the lowest values of harvesting costs were the operating cost for peanut digger was (88.08 LE/fad.), digging losses cost was (177.07 LE/fad.) and the operating cost for a special peanut combine was(210.62 LE/fad.), combine losses cost was (152.37 LE/fad.), where the price of kilogram for peanut was 2.40

\footnotetext{
Corresponding author: Tel. : +201285350797

E-mail address: dr.mostafa_ali@yahoo.com
} 
LE. (Ibrahim et al., 2008) developed a multipurpose digger for harvesting root crops (potato and peanut), the developed digger was tested at three levels of forward speeds (1.4, 1.8 and 2.3 $\mathrm{km} / \mathrm{hr}$.), for peanut and three different tilt angles $\left(12^{\circ}, 18^{\circ}\right.$ and $\left.24^{\circ}\right)$. From the obtained results, it was cleared that proper conditions to operate the developed digger were $15 \mathrm{~cm}$ harvesting depth, $2.3 \mathrm{~km} / \mathrm{hr}$., forward speed and $0.21 \mathrm{rad}\left(12^{\circ}\right)$ tilt angle. The cost of harvesting using the digger was $101.24 \mathrm{LE} / \mathrm{fad}$., for peanut. (Shuqi et al., 2009) determined that the parameters of the field performance tests of a new kind of combination device for digging and lifting peanut are as follows: peanut picking rate $\geq 99.6 \%$, total loss rate $\leq 3.3 \%$, picking breakage rate $\leq 2.0 \%$ and peanut impurity rate $\leq 2.2 \%$. (Suryawanshi et al., 2009) evaluated the performance of three types of groundnut digging blades; straight, inverted $\mathrm{V}$ and crescent shaped. The minimum draft of $156.56 \mathrm{~kg}$ was obtained for straight shear at the combination of $10^{\circ}$ rake angle and $15.5 \%$ soil moisture content. The straight shaped tool was selected as best tool for harvesting of the groundnut, which gave the maximum harvesting efficiency at the minimum of the draft. (Alexandru et al., 2011) designed and developed a functional model of a harvesting peanuts machine to achieve direct harvesting of peanuts. The results showed that the increase of the linear speed of the belts determined decrease of the separation degree of pods. The working speed of the machine should be from 0.61 to $0.92{\mathrm{~m} . \mathrm{sec}^{-1}}^{-1}$ and the linear speed of the pulling out device from 1.56 to $2.50 \mathrm{~m} . \mathrm{sec}^{-1}$. (Zaied et al., 2014) designed and fabricated a powered groundnut harvesting machine. The machine was tested in sandy and clayey sand soil. It was found that the effective time and total time recorded by the machine in sandy soil were lower than in clayey sand soil by $0.050 \mathrm{hr}$. Fuel consumption rate in sandy soil was lower than that in clayey sand soil by $0.29 \mathrm{l} / \mathrm{fad}$. Machine field speed in sandy soil was higher than speed in clayey sand soil by $0.69 \mathrm{~km} / \mathrm{hr}$., while field efficiency in clayey sand soil was higher than that in sandy soil by $1.2 \%$.

The objectives of this work are:

1. Manufacturing a machine to be suitable for direct harvesting of peanut crop.

2. Optimize some operating parameters (forward speed, chains linear speed and soil moisture content) affecting the performance of the developed machine.

3. Evaluate the developed machine from the economic point of view.

\section{MATERIALS AND METHODS}

Field experiments were carried out using peanut harvesting machine during two agricultural seasons of 2015 and 2016 in an area about three faddans at El-Qureen city, Sharkia Governorate, Egypt. Peanut crop planted mechanically to evaluate the performance of a harvesting machine suitable for direct harvesting of peanut. The mechanical analysis of the experimental soil was classified as sandy soil with $87.3 \%$ sandy percent.

\section{Materials}

\section{Crop}

The peanut (Arachis hypogaea L.) Giza 6 variety is one of the legumes family. This is a herbage annually, row spacing ranges from 65 to $70 \mathrm{~cm}$. Pods grow under the soil, it take away under surface up to $14 \mathrm{~cm}$ depth.

\section{Tractor}

The technical specifications of the tractor are as shown in Table 1.

Table 1. Technical specifications of the tractor

\begin{tabular}{lc}
\hline Type & Kubota D902 \\
\hline Power at rate speed & $17.2 \mathrm{~kW}(23.0 \mathrm{hP})$ \\
PTO revolution & $540 \mathrm{rpm}$ \\
PTO horsepower at $\mathbf{3 2 0 0} \mathbf{~ r p m}$ & $13.2 \mathrm{~kW}(17.7 \mathrm{hP})$ \\
Tractor mass & $700 \mathrm{~kg}$ \\
\hline
\end{tabular}




\section{Developed machine}

The developed machine as shown in Fig. 1 was fabricated from low costs local materials, and completely manufactured in local workshop, Faquas District, Sharkia Governorate, Egypt which performs direct harvesting of peanuts. The developed machine consisted mainly of digging and dislocation unit, separating unit, cleaning unit, conveying unit, transmission system, main frame and land wheels. The developed machine trailer behind the tractor, the movement was powered from the tractor PTO.

\section{Digging and dislocation unit}

Digging and dislocation unit consist of straight-shaped digging blade with sweep angle $180^{\circ}$. The digging depth was adjusted to be 15 $\mathrm{cm}$. Double chains with fingernails lift the loosened plant above the soil surface follows the digging blade and move plant to the end of the machine. The chains take power from PTO.

\section{Separating unit}

Separating unit consist of a set of belts with rubber fingers operated by pulleys to achieve the stripping operation without any pods damage, where the root zone loaded with pods enters into fingers which move in the opposite direction of movement of the plant in order to work on separation of the pod from the needle.

\section{Cleaning unit}

Cleaning unit is a sieve, which clean and separate peanut pods from the soil then transfers them to the conveyor. It takes oscillation movement from the bottom conveyer drum by pulley and pin. The oscillation distance $12 \mathrm{~cm}$.

\section{Conveying unit}

The rubber elevator consists of two drums which are fixed on two bearings. A conveyer belt rotates around the drums. The belt tension is adjusted by screw bolts attached to the bearings. It is used for lifting pods from the sieve to the collected bag. The elevator is operated by means of pulleys and belts powered from pulley on the main chain's shaft, with changed the rotation direction from horizontal direction to vertical direction.

\section{Transmission system}

The machine is operated by machine gear box powered from PTO of a tractor. The power is transmitted from gear box to the other moving parts by means of pulleys and belts with different speed ratios.

\section{Main frame}

The all previous units and their parts were fixed on the frame. The main frame was made of iron steel U-section. It was carried by two tire ground wheels of $50 \mathrm{~cm}$ diameter.

\section{Methods}

A field experiments were carried out in Abo Nour farm, El-Qureen city, Sharkia Governorate, Egypt. To evaluate the developed peanut harvesting machine, which performs direct harvesting of peanuts, following the next stages: Dislocation of the plants in conditions of low humidity, pulling the plants out of the soil, removing the pods and eliminating impurities.

The performance of the developed machine was experimentally measured under the following parameters:

1-Four different forward speeds of 1.5, 2, 2.5 and $3 \mathrm{~km} / \mathrm{hr}$.

2-Four different chain speeds of 53.33, 61.67, 70.00 and $78.33 \mathrm{~m} / \mathrm{min}$.

3- Four different soil moisture contents (d.b.) of 9.3, 12.4, 15.7 and $18.6 \%$.

\section{Measurements and determinations}

Evaluation of the performance of developed machine was based on the following indicators:

\section{Field capacity}

The theoretical field capacity was determined from the following formula (Kepner et al., 1978):

$$
\mathrm{TFC}=\frac{\mathrm{F}_{\mathrm{s}} \times \mathrm{W}_{\mathrm{m}}}{4.2}
$$

Where:

$\mathrm{TFC}=$ the theoretical field capacity of the machine (fad./hr.).

$\mathrm{F}_{\mathrm{s}}=$ Forward speed $(\mathrm{km} / \mathrm{hr}$.].

$\mathrm{W}_{\mathrm{m}}=$ Working width of the machine (m).

The effective field capacity can be determined from the following equation:

$$
\mathrm{EFC}=\frac{60}{\mathrm{Tu}+\mathrm{Ti}}
$$



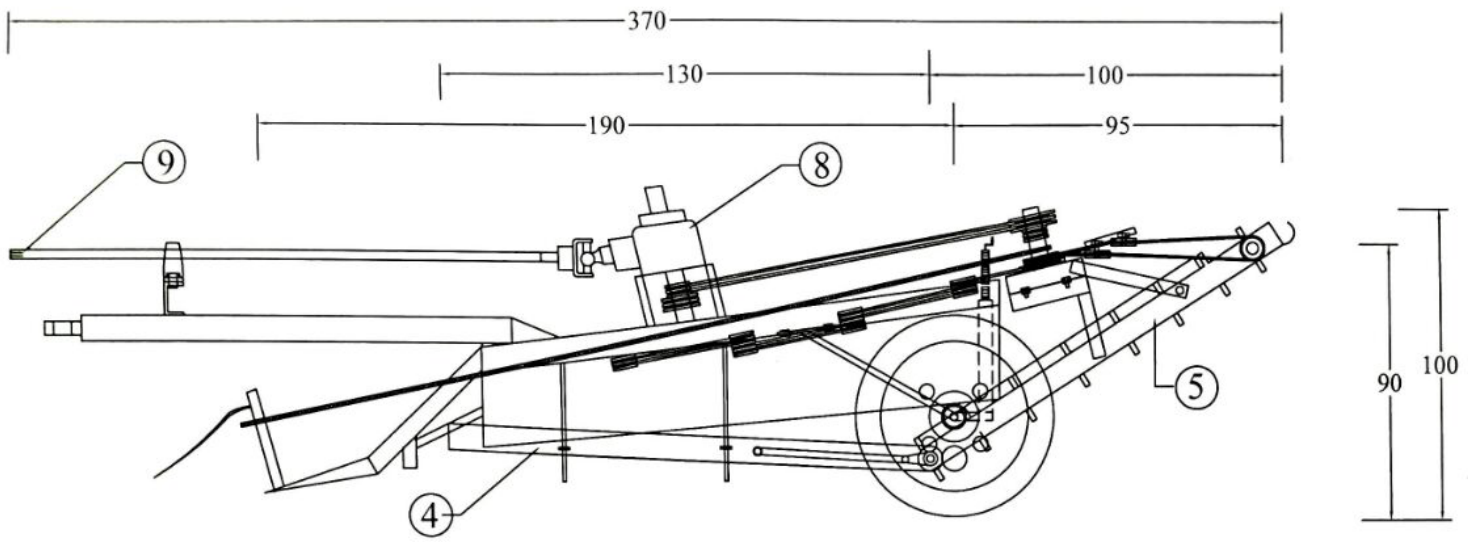

Elevation

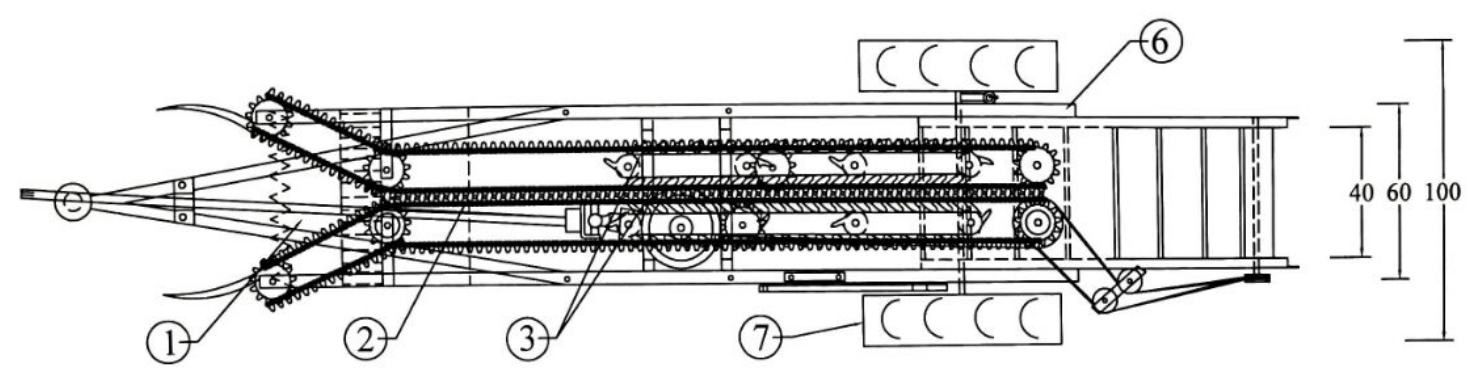

All dimensions in cm.

Plan

\begin{tabular}{cccccc}
\hline No. & Part name & No. off & No. & Part name & No. off \\
\hline 1 & Shear & 1 & 6 & Main frame & 1 \\
2 & Chains & 2 & 7 & Wheels & 2 \\
3 & Separating belts & 12 & 8 & Gear box & 1 \\
4 & Sieve & 1 & 9 & Universal joint of PTO & 1 \\
5 & Conveyer & 1 & 9 & & \\
\hline
\end{tabular}

Fig. 1. The views of the developed machine

Where:

$\mathrm{EFC}=$ The effective field capacity of the machine (fad./hr.).

$\mathrm{Tu}=$ The utilized time per faddan (min.).

$\mathrm{Ti}=$ The summation of lost time per faddan (min.).

\section{Field efficiency}

The field efficiency is calculated by using the following formula:

$$
\eta f=\frac{E F C}{T F C} \times 100
$$

Where:

$\eta \mathrm{f}=$ The field efficiency of the machine (\%).

$\mathrm{EFC}=$ The effective field capacity of the machine [fad./hr.].

TFC $=$ Theoretical field capacity of the machine [fad./hr.].

\section{Total yield}

The yield was measured and calculated per faddan.

\section{Productivity}

The yield productivity was measured according 
the following formula:

$$
\mathrm{p}=\mathrm{y} \times \mathrm{EFC}
$$

Where:

$\mathrm{p}=$ Productivity $(\mathrm{Mg} / \mathrm{hr}$.).

$\mathrm{y}=$ Total yield, [Mg/fad.].

$\mathrm{EFC}=$ The effective field capacity of the machine (fad./hr.).

\section{Harvesting losses}

Harvesting losses, including, digging losses and separating losses were determined from the following equations:

Digging losses $(\%)=\frac{\text { Weight of digging losses }(\mathrm{kg} / \mathrm{fad} \text {. })}{\text { Weight of total yield }(\mathrm{kg} / \mathrm{fad} \text {. })} \times 100$

Separating losses $(\%)=\frac{\text { Weight of separating losses }(\mathrm{kg} / \mathrm{fad} .)}{\text { Weight of total yield }(\mathrm{kg} / \mathrm{fad} .)} \times 100$

Harvesting losses $(\%)=\frac{\text { Weight of harvesting losses }(\mathrm{kg} / \mathrm{fad} .)}{\text { Weight of total yield }(\mathrm{kg} / \mathrm{fad} .)} \times 100$

\section{Required power}

The required power was calculated by using the following formula (Hunt, 1983):

$$
\mathrm{EP}=\text { f.c. }(1 / 3600) \rho_{\mathrm{f}} \times \text { l.c.v. } \times 427 \times \eta_{\text {th }} \times \eta_{\mathrm{m}} \times \frac{1}{75} \times \frac{1}{1.36}
$$

Where:

$\mathrm{EP}=$ Required power $(\mathrm{kW})$.

$\mathrm{fc}_{\mathrm{C}}=$ Rate of fuel consumption (l/hr.).

$\rho_{\mathrm{f}}=$ Density of fuel $(\mathrm{kg} / \mathrm{l})$ (for diesel engines $=$ $0.85 \mathrm{~kg} / \mathrm{l}$ )

l.c.v.=Average calorific value of fuel (11000 $\mathrm{k.cal} / \mathrm{kg}$ ).

$\eta_{\text {thb }}=$ Thermal efficiency of the engine, (Considered to be 30\% for diesel engines)

427 = Thermo - mechanical equivalent $(\mathrm{kg} . \mathrm{m} /$ kcal).

$\eta_{\mathrm{m}}=$ Mechanical efficiency of the engine, (Considered to be $83 \%$ for diesel engines)

\section{Specific energy}

Energy requirements can be calculated by the following equation:

$$
\mathrm{SE}=\frac{\mathrm{EP}}{\mathrm{EFC}}
$$

Where:

$\mathrm{SE}=$ Specific energy requirements (kW.hr./fad.).

$\mathrm{EP}=$ Required power $(\mathrm{kW})$.

$\mathrm{EFC}=$ the effective field capacity of the machine (fad./hr.).

\section{Cost analysis}

The cost of mechanized process was based on the initial cost of machine, interest on capital, cost of fuel and oil consumed, cost of maintenance, and wage of operator according to the following formula (Awady, 1978):

$$
\mathrm{C}=\frac{\mathrm{p}}{\mathrm{h}}\left(\frac{1}{\mathrm{a}}+\frac{\mathrm{i}}{2}+\mathrm{t}+\mathrm{r}\right)+(1.2 \mathrm{~W} \times \mathrm{s} \times \mathrm{f})+\frac{\mathrm{m}}{144}
$$

Where:

$\mathrm{C}=$ Hourly cost (LE/hr.).

$\mathrm{p}=$ price of machine (LE).

$\mathrm{h}=$ Yearly working hours (hr./year).

$\mathrm{a}=$ Life expectancy of the machine (year).

$\mathrm{i}=$ Annual Interest rate, [\%].

$\mathrm{t}=$ Annual Taxes, over heads rate (\%).

$\mathrm{r}=$ Annual Repairs and maintenance rate (\%).

$\mathrm{f}=$ fuel price (LE).

1.2= A factor including reasonable estimation of the oil consumption in addition to fuel.

$\mathrm{W}=$ Engine power (hp).

$\mathrm{s}=$ Specific fuel consumption (l/hp.hr.).

$\mathrm{m}=$ Monthly average wage (LE).

144=Reasonable estimation of monthly working hours.

\section{Operating cost}

Operational cost can be determined using the following formula:

$$
\text { Operating cost }=\frac{C}{E F C}(\mathrm{LE} / \text { fad. })
$$

Where:

$\mathrm{C}=$ Hourly cost, [LE/hr.].

$\mathrm{EFC}=$ the effective field capacity of the machine (fad./hr.). 


\section{Criterion (total) cost:}

The criterion cost required for the harvesting operation was estimated using the following equation (Awady et al., 1982):

Criterion cost $=$ operating cost + pods losses cost (LE /fad.)

Where, the price of kilogram for peanut was taken to be $10.00 \mathrm{LE}$.

\section{RESULTS AND DISCUSSION}

\section{The Obtained Results will be Discussed under the Following Items}

\section{Influence of forward speed and chain speed on filed capacity and field efficiency at different soil moisture contents}

Representative values of both filed capacity and field efficiency at different forward speed and chain speed and different soil moisture contents are given in Fig. 2. It is clear that filed capacity was increased by increasing forward speed up to $3.00 \mathrm{~km} / \mathrm{hr}$., while results show that increasing forward speed decreased field efficiency up to $3.00 \mathrm{~km} / \mathrm{hr}$.

Considering $53.33 \mathrm{~m} / \mathrm{min}$ chain speed (A), obtained results show that increasing forward speed from 1.50 to $3.00 \mathrm{~km} / \mathrm{hr}$., measured at different soil moisture contents of about 9.3, 12.4, 15.7 and $18.6 \%$, increased filed capacity from 0.260 to 0.442 , from 0.273 to 0.454 , from 0.284 to 0.466 and from 0.267 to 0.449 fad./hr., while decreased field efficiency from 81.00 to 68.74, from 85.05 to 70.61 , from 88.47 to 72.47 and from 83.18 to $69.83 \%$, respectively.

As to $61.67 \mathrm{~m} / \mathrm{min}$., chain speed (B), results show that increasing forward speed from 1.50 to $3.00 \mathrm{~km} / \mathrm{hr}$., measured at different soil moisture contents of about 9.3, 12.4, 15.7 and 18.6\%, increased filed capacity from 0.272 to 0.457 , from 0.279 to 0.468 , from 0.289 to 0.482 and from 0.275 to $0.463 \mathrm{fad} . / \mathrm{hr}$., while decreased field efficiency from 84.74 to 71.07 , from 86.92 to 72.78 , from 90.03 to 74.96 and from 85.67 to $72.01 \%$, respectively.

With respect to $70.00 \mathrm{~m} / \mathrm{min}$ chain speed (C), results show that increasing forward speed from 1.50 to $3.00 \mathrm{~km} / \mathrm{hr}$., measured at different soil moisture contents of about 9.3, 12.4, 15.7 and $18.6 \%$, increased filed capacity from 0.274 to 0.469 , from 0.283 to 0.483 , from 0.292 to 0.503 and from 0.279 to 0.478 fad./hr., while decreased field efficiency from 85.36 to 72.94 , from 88.16 to 75.12 , from 90.97 to 78.23 and from 86.92 to $74.34 \%$, respectively.

Regarding $78.33 \mathrm{~m} / \mathrm{min}$ chain speed (D), results show that increasing forward speed from 1.50 to $3.00 \mathrm{~km} / \mathrm{hr}$., measured at different soil moisture contents of about 9.3, 12.4, 15.7 and $18.6 \%$, increased filed capacity from 0.255 to 0.449 , from 0.269 to 0.455 , from 0.273 to 0.468 and from 0.267 to 0.454 fad./hr., while decreased field efficiency from 79.44 to 69.83, from 83.80 to 70.76 , from 85.05 to 72.78 and from 83.18 to $70.61 \%$, respectively.

Influence of forward speed and chain speed on productivity and total harvesting losses at different soil moisture contents

Representative values of both productivity and total harvesting losses at different forward speed and chain speed and different soil moisture contents are given in Fig. 3. It is noticed that productivity was increased by increasing forward speed up to $3.00 \mathrm{~km} / \mathrm{hr}$., and also results show that increasing forward speed increased total harvesting losses up to $3.00 \mathrm{~km} / \mathrm{hr}$.

Respecting $53.33 \mathrm{~m} / \mathrm{min}$ chain speed (A), obtained results show that increasing forward speed from 1.50 to $3.00 \mathrm{~km} / \mathrm{hr}$., measured at different soil moisture contents of about 9.3, 12.4, 15.7 and 18.6\%, increased productivity from 0.445 to 0.743 , from 0.478 to 0.783 , from 0.506 to 0.812 and from 0.473 to $0.777 \mathrm{Mg} / \mathrm{hr}$., and also increased total harvesting losses from 2.31 to 2.83 , from 1.62 to 2.58 , from 1.09 to 1.56 and from 1.10 to $1.57 \%$, respectively.

In respect of $61.67 \mathrm{~m} / \mathrm{min}$ chain speed (B), at the same pervious conditions, the results show that productivity was increased from 0.471 to 0.772 , from 0.492 to 0.816 , from 0.517 to 0.852 and from 0.491 to $0.811 \mathrm{Mg} / \mathrm{hr}$., and also increased total harvesting losses from 2.32 to 2.82, from 1.68 to 2.09 , from 1.10 to 1.57 and from 1.12 to $1.58 \%$, respectively.

With regard to $70.00 \mathrm{~m} / \mathrm{min}$ chain speed (C), at the same pervious conditions, the results show that productivity was increased from 0.477 to 


\begin{tabular}{|llll|}
\hline _ Actual field capacity (fad./hr.) & $\ldots \ldots$ & Field efficiency (\%) \\
\hline
\end{tabular}
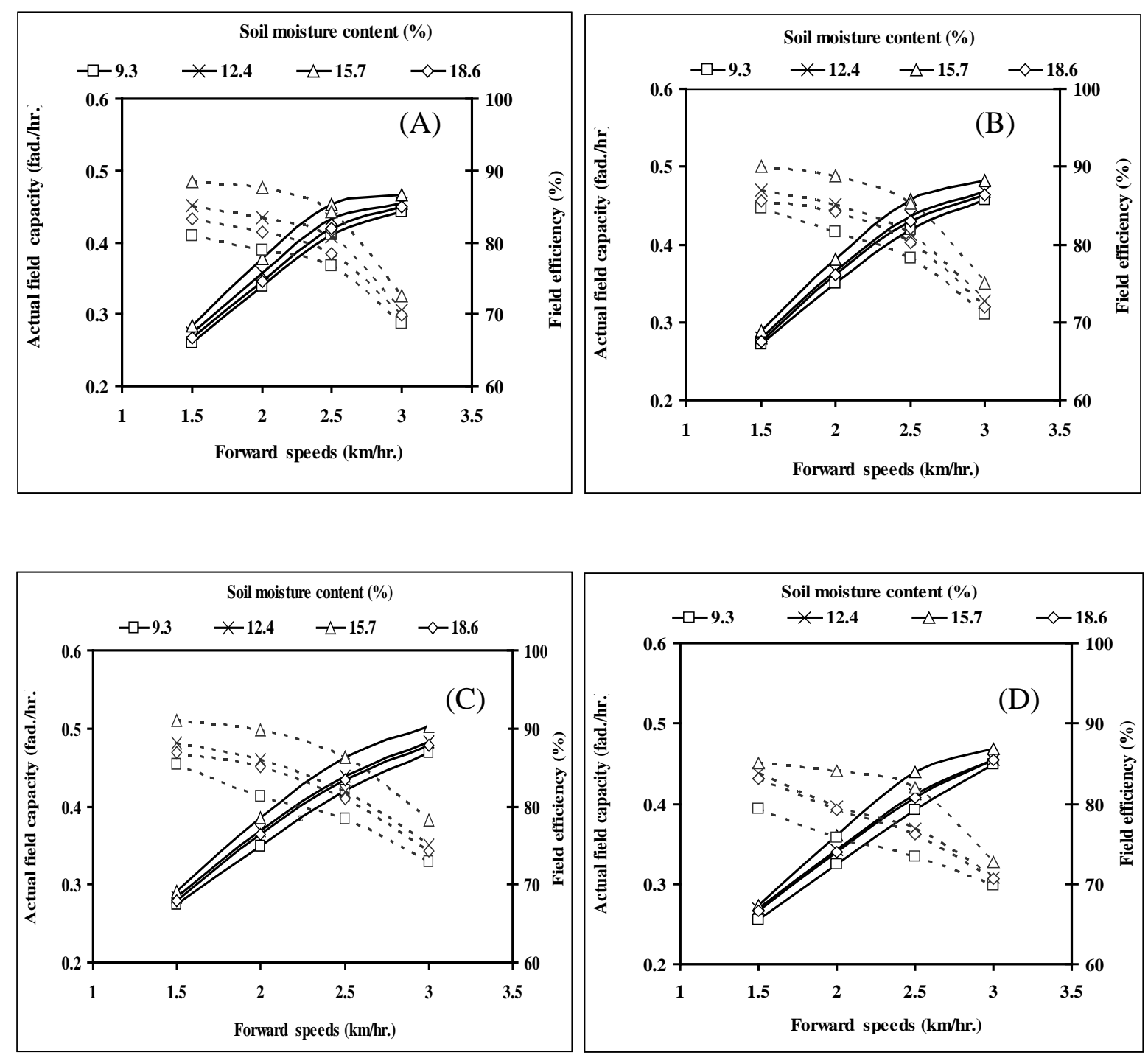

Fig.2. Effect of forward speed and chain speed on filed capacity and field efficiency at different soil moisture contents 



Fig.3. Effect of forward speed and chain speed on productivity and total harvesting losses at different soil moisture contents 
0.800 , from 0.504 to 0.848 , from 0.530 to 0.898 and from 0.501 to $0.843 \mathrm{Mg} / \mathrm{hr}$., and also increased total harvesting losses from 2.32 to 2.84, from 1.69 to 2.14 , from 1.11 to 1.58 and from 1.14 to $1.58 \%$, respectively.

With respect to $78.33 \mathrm{~m} / \mathrm{min}$ chain speed (D), at the same pervious conditions, the data show that productivity was increased from 0.440 to 0.738 , from 0.476 to 0.786 , from 0.490 to 0.829 and from 0.475 to $0.781 \mathrm{Mg} / \mathrm{hr}$., and also increased total harvesting losses from 2.51 to 3.05 , from 1.85 to 2.30 , from 1.27 to 1.97 and from 1.28 to $2.02 \%$, respectively.

Influence of forward speed and chain speed on specific energy and criterion cost at different soil moisture contents

Representative values of both specific energy and criterion cost at different forward speed and chain speed and different soil moisture content are given in Fig. 4. It is clear that specific energy was decreased by increasing forward speed up to $3.00 \mathrm{~km} / \mathrm{hr}$., and also results show that increasing forward speed, decreased criterion cost up to $2.50 \mathrm{~km} / \mathrm{hr}$., any further increase in forward speed up to $3.00 \mathrm{~km} / \mathrm{hr}$., criterion cost will increase.

In relation to $53.33 \mathrm{~m} / \mathrm{min}$., chain speed (A), obtained results show that increasing forward speed from 1.50 to $3.00 \mathrm{~km} / \mathrm{hr}$., measured at different soil moisture contents of about 9.3, $12.4,15.7$ and $18.6 \%$, decreased specific energy from 66.46 to 48.52 , from 57.33 to 41.83 , from 52.82 to 38.05 and from 56.48 to $40.23 \mathrm{~kW}$.hr./ fad., and also decreased criterion cost from 619.88 to 584.50 , from 485.96 to 460.94 , from 383.03 to 353.19 and from 396.73 to $365.73 \mathrm{LE}$ /fad., respectively. The further increase in forward speed more than 2.5 up to $3.00 \mathrm{~km} / \mathrm{hr}$., measured at the same previous soil moisture contents increased criterion cost from 584.50 to 629.45, from 460.94 to 581.27, from 353.19 to 394.66 and from 365.73 to $400.77 \mathrm{LE} /$ fad., respectively.

As to $61.67 \mathrm{~m} / \mathrm{min}$ chain speed (B), at the same pervious conditions, the data showed that specific energy decreased from 61.14 to 47.09 , from 53.76 to 40.80 , from 48.51 to 35.98 and from 53.02 to $39.21 \mathrm{~kW} . \mathrm{hr} . /$ fad., and also decreased criterion cost from 612.67 to 583.83, from 492.58 to 461.90 , from 381.60 to 350.11 and from 394.55 to $362.80 \mathrm{LE} /$ fad., respectively. The further increase in forward speed more than
2.5 up to $3.00 \mathrm{~km} / \mathrm{hr}$., measured at the same previous soil moisture contents increased criterion cost from 583.83 to 623.71, from 461.90 to 489.58 , from 350.11 to 392.68 and from 362.80 to $399.00 \mathrm{LE} /$ fad., respectively.

As for $70.00 \mathrm{~m} / \mathrm{min}$., chain speed (C), at the same pervious conditions, the results showed that decreased specific energy from 59.49 to 44.48, from 50.67 to 39.15 , from 46.88 to 32.92 and from 49.75 to $36.20 \mathrm{~kW} . \mathrm{hr} . / \mathrm{fad}$., and also decreased criterion cost from 611.25 to 585.33, from 491.69 to 461.07 , from 381.51 to 345.00 and from 395.38 to $361.66 \mathrm{LE} / \mathrm{fad}$., respectively. The further increase in forward speed more than 2.5 up to $3.00 \mathrm{~km} / \mathrm{hr}$., measured at the same previous soil moisture contents increased criterion cost from 585.33 to 624.33, from 461.07 to 495.06 , from 345.00 to 389.89 and from 361.66 to $395.40 \mathrm{LE} /$ fad., respectively.

With reference to $78.33 \mathrm{~m} / \mathrm{min}$ chain speed (D), at the same pervious conditions, the results showed that specific energy was decreased from 62.63 to 45.75 , from 52.12 to 40.13 , from 48.97 to 33.92 and from 51.27 to $38.49 \mathrm{~kW} . \mathrm{hr}$./fad., and also decreased criterion cost from 659.88 to 628.21 , from 530.25 to 510.39 , from 422.96 to 396.27 and from 429.13 to $412.65 \mathrm{LE} /$ fad., respectively. The further increase in forward speed more than 2.5 up to $3.00 \mathrm{~km} / \mathrm{hr}$., measured at the same previous soil moisture contents increased criterion cost from 628.21 to 667.17, from 510.39 to 530.62 , from 396.27 to 467.98 and from 412.65 to $480.47 \mathrm{LE} /$ fad., respectively.

Criterion cost decreased with forward speed up to $2.5 \mathrm{~km} / \mathrm{hr}$., and after that increase due to decrease operating cost and increase total harvesting losses, but increasing in total harvesting losses more than decreasing in operating cost.

\section{Conclusion}

From obtained results, the following conclusions can be taken:

- The proper values of filed capacity and efficiency were $0.463 \mathrm{fad} / \mathrm{hr}$., and $86.38 \%$, respectively at $2.5 \mathrm{~km} / \mathrm{hr}$., forward speed, $70.00 \mathrm{~m} / \mathrm{min}$ chain speed and $15.7 \%$ soil moisture content.

The proper values of specific energy and criterion cost were $33.80 \mathrm{~kW} . \mathrm{hr}$./fad., and $345.00 \mathrm{LE} / \mathrm{fad}$., respectively at the same previous conditions. 

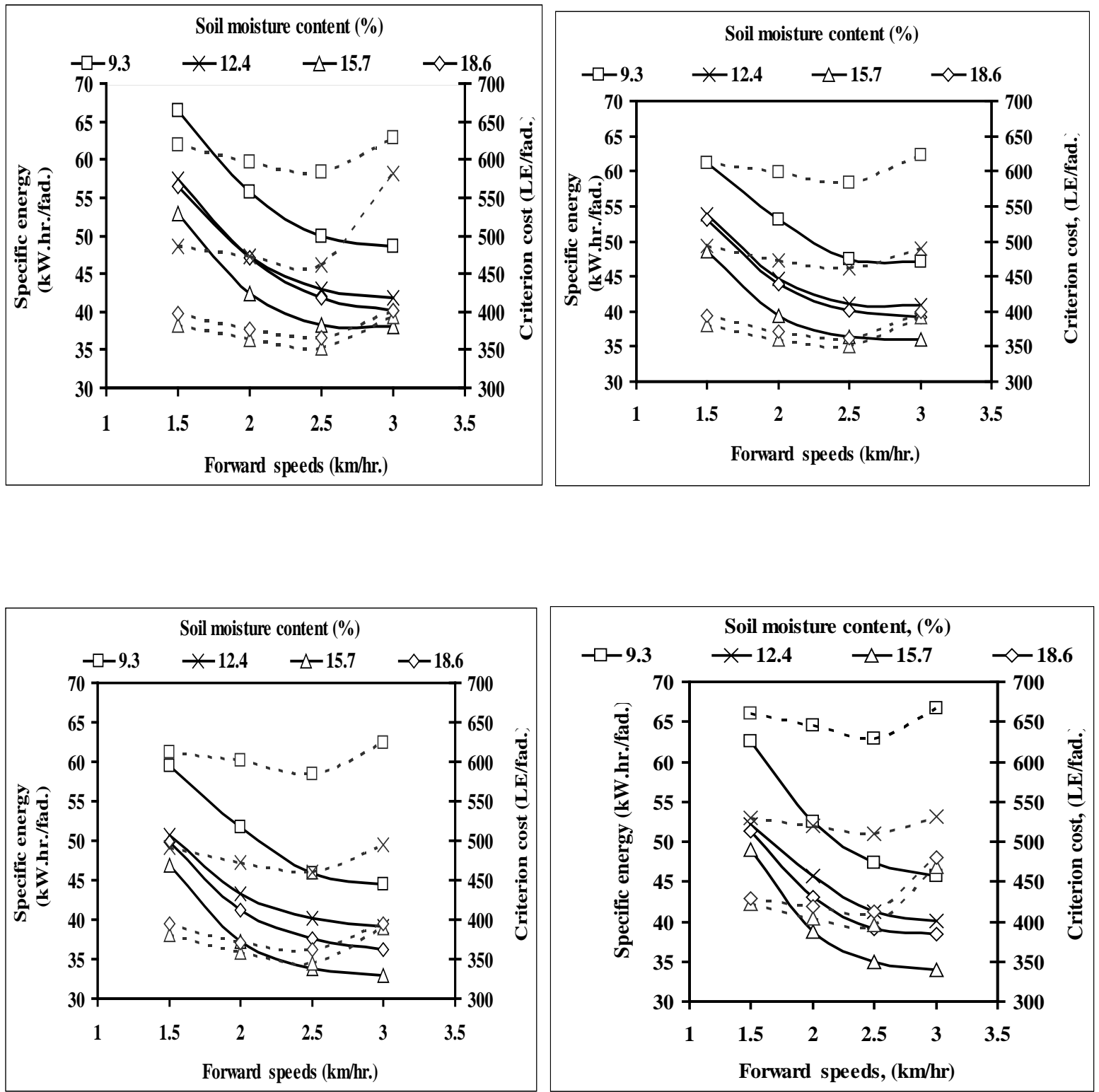

Fig. 4. Effect of some operating parameters on specific energy and criterion cost at different chain speeds 


\section{REFERENCES}

Alexandru, T., M. Glodeanu, S. Boruz and S. Popescu (2011). Experimental research on mechanized harvesting of peanuts in Romania. Eng. for Rural Develop. Jelgava, 40: 137-141.

Awady, M.N. (1978). Tractor and Farm Machinery. Text book, Fac. Agric., AinShams Univ., Cairo, Egypt, 164-167.

Awady, M.N., E.Y. Ghoniem and A.I. Hashish (1982). A critical comparison between wheat combine harvesters under Egyptian conditions. R.S. No. 1920, Ain-Shams Univ. J. 1982.

Hunt, D. (1983). Farm Power and Machinery Management. $8^{\text {th }}$ Ed. Iowa State Univ., Press Ames, USA. Ames, Iowa, USA, 364-368.

Ibrahim, M.M., E.A. Amin and A. Farag (2008). Developing a multi- purpose digger for harvesting root crops. Misr J. Agric. Eng., 25 (4): 1225-1239.

Kepner, R.A., R. Bainer and E.L. Barger (1978). Principles of Farm Machinery, $3^{\text {rd }}$ Ed; Ch. On Peanut Harv., 468-470.
Mechail, W.M. (2003). Complete mechanization system for peanut planting and harvesting under Egyptian Conditions. Misr J. Agric. Eng., 20 (4): 146-160.

Mussad, E.A.O. (2001). Development of a tractor mounted peanut harvesting equipment. Ph.D. Thesis, Univ., Putra Malaysia.

Shuqi, Sh., L. Guoying, Y. Ranbing, S. Tongzhen, W. Yanyao and L. Zhengguo (2009). Development of 4HQL-2 type wholefeed peanut combine. J. Transactions of the CSAE, 25 (6): 125-130.

Suryawanshi, S.H., K. Kathirvel and B. Shridar (2009). Comparative evaluation of different groundnut digging blades. AMA, 40 (1) : 9-11.

USDA (2016). United States Department of Agriculture. Table 13 peanut area, yield and production. https : apps. fas. usda. gov / psdonline/ circulars/production.pdf

Zaied, M.B., A.M. El-Naim, M.H. Dahab and A.S. Mahgoub (2014). Development of powered groundnut harvester for small and medium holdings in north kordofan state in Western Sudan. World J. Agric. Res., 2(3): 119-123. 


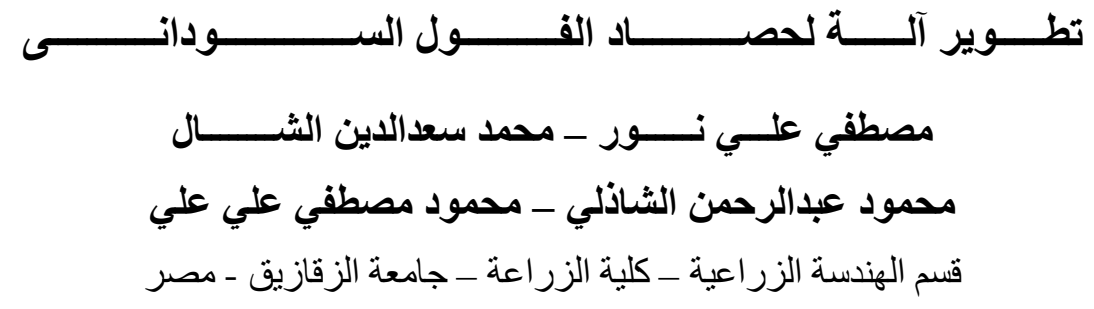

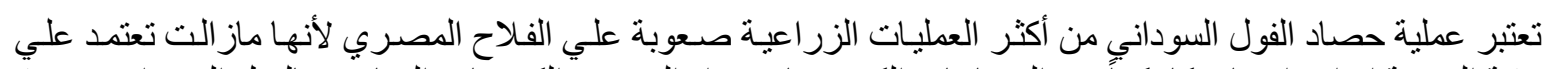

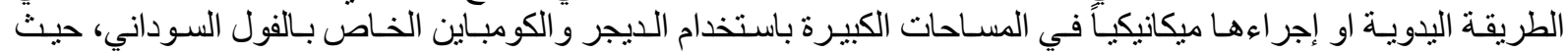

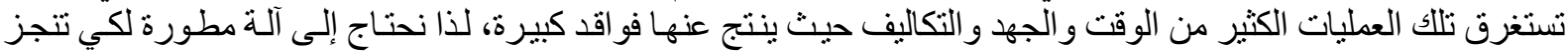

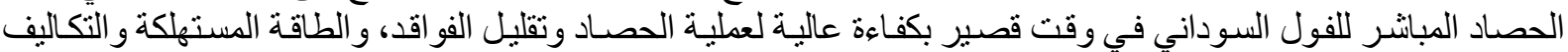

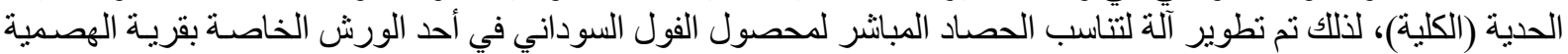

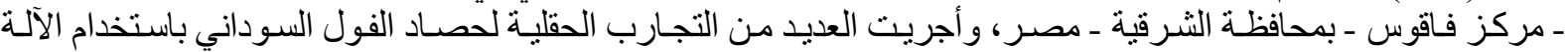

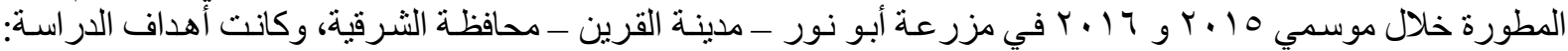

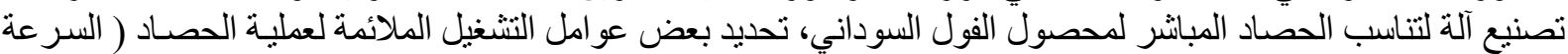

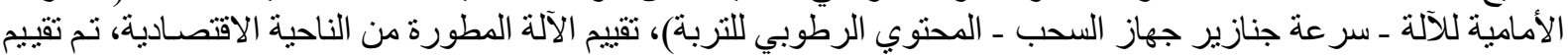

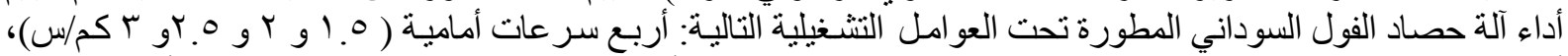

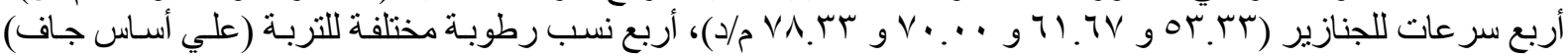

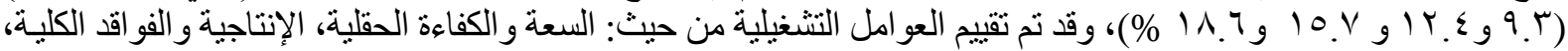

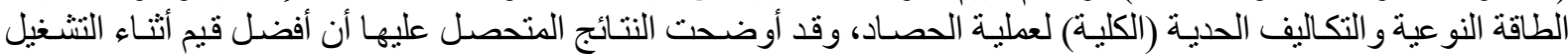

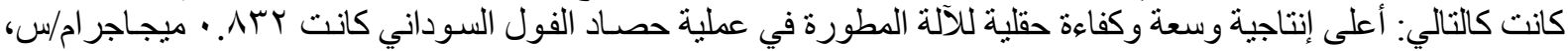

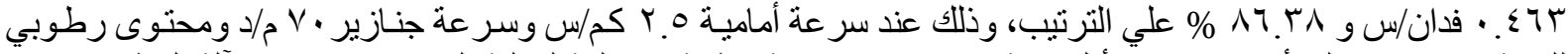

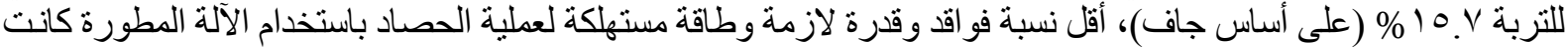

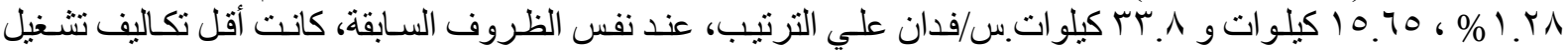

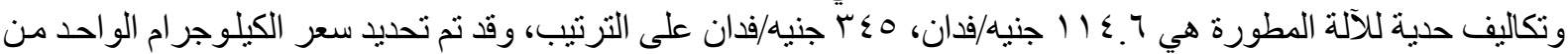

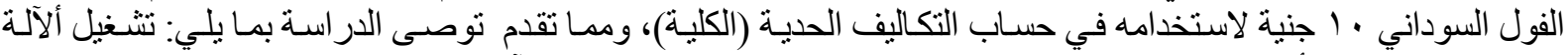

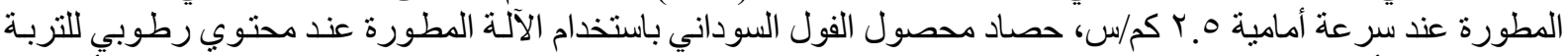

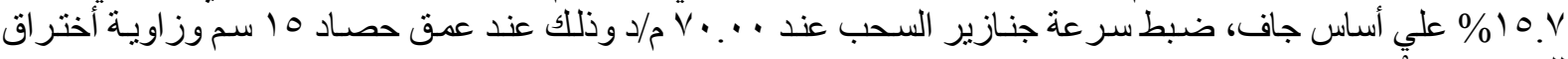

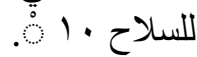

أستاذ الهندسة الزر اعية المتفرغ - كلية الزر اعية ـ جامعة المنصورة.

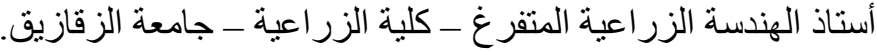

